Biology, Controls and Models of Tree Volatile Organic Compound Emissions 


\section{Tree Physiology}

\section{Volume 5}

Series Editors: Frederick C. Meinzer and Ülo Niinemets

For further volumes:

http://www.springer.com/series/6644 
Ülo Niinemets • Russell K. Monson Editors

Biology, Controls and Models of Tree Volatile Organic Compound Emissions

䡒 Springer 


\section{Editors}

Ülo Niinemets

Institute of Agricultural and Environmental Sciences

Estonian University of Life Sciences

Tartu, Estonia

\author{
Russell K. Monson \\ School of Natural Resources and the \\ Environment \\ University of Arizona \\ Tucson, AZ, USA
}

ISSN 1568-2544

ISBN 978-94-007-6605-1

ISBN 978-94-007-6606-8 (eBook)

DOI 10.1007/978-94-007-6606-8

Springer Dordrecht Heidelberg New York London

Library of Congress Control Number: 2013942975

(C) Springer Science+Business Media Dordrecht 2013

This work is subject to copyright. All rights are reserved by the Publisher, whether the whole or part of the material is concerned, specifically the rights of translation, reprinting, reuse of illustrations, recitation, broadcasting, reproduction on microfilms or in any other physical way, and transmission or information storage and retrieval, electronic adaptation, computer software, or by similar or dissimilar methodology now known or hereafter developed. Exempted from this legal reservation are brief excerpts in connection with reviews or scholarly analysis or material supplied specifically for the purpose of being entered and executed on a computer system, for exclusive use by the purchaser of the work. Duplication of this publication or parts thereof is permitted only under the provisions of the Copyright Law of the Publisher's location, in its current version, and permission for use must always be obtained from Springer. Permissions for use may be obtained through RightsLink at the Copyright Clearance Center. Violations are liable to prosecution under the respective Copyright Law.

The use of general descriptive names, registered names, trademarks, service marks, etc. in this publication does not imply, even in the absence of a specific statement, that such names are exempt from the relevant protective laws and regulations and therefore free for general use.

While the advice and information in this book are believed to be true and accurate at the date of publication, neither the authors nor the editors nor the publisher can accept any legal responsibility for any errors or omissions that may be made. The publisher makes no warranty, express or implied, with respect to the material contained herein.

Printed on acid-free paper

Springer is part of Springer Science+Business Media (www.springer.com) 


\section{Preface}

\section{Ülo Niinemets and Russell K. Monson}

Discoveries that plants are in part responsible for the blue haze commonly observed in the atmosphere above many forests (Went 1960; Rasmussen and Went 1965) and for the tropospheric ozone pollution in many forested urban and suburban areas (Rasmussen 1972; Chameides et al. 1988) have compelled researchers to ask what are the plants emitting, how much is being emitted and how do these emissions impact our environment? These very important questions are at the heart of a highly interdisciplinary research field: biogenic volatile organic compounds (BVOC) in the biosphere-atmosphere component of the Earth system.

Fritz Went, a plant physiologist famous for discoveries on plant growth regulators, was also intrigued by the potential for plants to form atmospheric hazes above forests. He hypothesized that the organic compounds emitted from plants, many of which he could detect with his own sense of smell, contributed to this haze. In 1960, he made measurements on the mass of leaf oils in shrubs from the Western United States and estimated global terpene emissions to be $175 \mathrm{Tg} \mathrm{C}_{\text {year }}{ }^{-1}$ ( $1 \mathrm{Tg}=10^{12} \mathrm{~g}$ ) (Went 1960). Since that seminal study, estimates of global BVOC emissions (excluding methane) have been refined through coupled vegetationatmosphere models and better maps of global vegetation. Currently, the worldwide emissions are estimated to be around $1 \mathrm{Pg} \mathrm{C}$ year $^{-1}\left(1 \mathrm{Pg}=10^{15} \mathrm{~g}\right.$ ) (Guenther et al. 2012). Much of the past research on plant volatile emissions has been, and continues to be, on the simple C5 volatile hydrocarbon, isoprene, which is emitted from leaves in a light- and temperature-dependent manner and is coupled to the metabolic processes of photosynthesis (Sanadze 1956; Rasmussen and Went 1965; Rasmussen 1970). Since its initial discovery, the research on biogenic isoprene has

\footnotetext{
Ü. Niinemets

Department of Plant Physiology, Institute of Agricultural and Environmental Sciences, Estonian University of Life Sciences, Tartu, Estonia

R.K. Monson

School of Natural Resources and the Environment and the Laboratory for Tree Ring Research, University of Arizona, Tucson, AZ 85721, USA
} 
focused on understanding its source strength and distribution among different plant taxa, resulting in the construction of first list of isoprene-emitting plants (Rasmussen 1978) and first biogenic emission inventory system (BEIS, Pierce and Waldruff 1991), followed by more biologically oriented emission algorithms and inventories (e.g., Guenther et al. 1991, 1994, 2006, 2012; Arneth et al. 2007; Monson et al. 2012). By now, it is widely acknowledged that multiple plant BVOC emissions play a major role in atmospheric dynamics within the Earth system with highly reactive compounds reacting in the gas phase to affect atmospheric chemistry, including influences on less reactive compounds that affect the atmosphere's global warming potential, e.g., methane (Fuentes et al. 2000). Furthermore, condensation of photooxidation products of BVOCs leads to the formation of secondary organic aerosols, which also generate cloud condensation nuclei and have profound implications for the Earth's solar radiation budget and climate (Kulmala et al. 2004; Huff Hartz et al. 2005; Hallquist et al. 2009; Arneth et al. 2010). Trees have been traditionally thought to contribute the most to BVOC emissions due to the presence of multiple tree species with high emission rates (e.g., the oaks and poplars) and large aerial coverage, which gives forests a unique global role in regulating atmospheric chemistry. Apart from strong constitutive emitters, emissions induced by abiotic and biotic stresses have also been identified in many important forest species previously considered "non-emitters" (Holopainen and Gershenzon 2010; Loreto and Schnitzler 2010; Niinemets 2010), implying that there are strong biological controls on the emissions of BVOCs that we still do not understand and that continue to cause large uncertainties in our models and inventories.

From a biological perspective, the key question has been why do plants emit these volatiles? What are the costs and benefits for the plant, and why do some plant species emit these compounds constitutively and in others the emissions must be induced? The role of isoprene emissions was unknown until the mid-1990s when it was discovered that isoprene enhances plant thermotolerance (Sharkey and Singsaas 1995) and increases the resistance of plant metabolism to atmospheric oxidants (Loreto et al. 2001), followed by the development of a hypothesis of general enhancement of cellular oxidative stress tolerance (Vickers et al. 2009a). Lately, breakthroughs in the genetic engineering of plants have allowed us to test these hypotheses with unprecedented specificity in the processes affected (Behnke et al. 2007, 2010; Vickers et al. 2009b; Velikova et al. 2011). Rapid developments in the availability of genomic information have also recently allowed researchers to gain insight into evolutionary patterns and past influences by natural selection on the isoprene emission capacity (Monson et al. 2013; Sharkey et al. 2013). Furthermore, the role of multiple plant BVOCs in abiotic and biotic stress signalling within and among plants, and among plants and insects has drawn strong attention from a broader complement of the ecological research community (Owen and Peñuelas 2005; Dicke et al. 2009; Dicke and Baldwin 2010; Holopainen and Gershenzon 2010).

In the past, three comprehensive treatises have been published on trace gas emission from vegetation (Sharkey et al. 1991; Hewitt 1999; Gasche et al. 2003). Only the book by Sharkey et al. (1991) deals exclusively with biological controls 
on BVOC, while the book by Hewitt (1999) focuses on quantification of emissions, and the book by Gasche et al. (2003) only briefly considers biological controls. Since the publication of these books, there has been rapid progress in understanding the controls over isoprene emissions, including the discovery of isoprene synthase (Silver and Fall 1991), its sequence in several organisms (e.g., Miller et al. 2001; Vickers et al. 2010; Sharkey et al. 2013) and establishment of the reaction mechanism (Köksal et al. 2010). Furthermore, there has been a significant increase in our knowledge of multiple terpene synthase structures and regulation (Bohlmann et al. 1998; Fischbach et al. 2001; Degenhardt et al. 2009; Chen et al. 2011; Keeling et al. 2011; Köksal et al. 2011). Due to the development of sensors and detection technology that was in its infancy at the time of the appearance of the book edited by Hewitt (1999), a large volume of literature has emerged on BVOC flux quantifications (Karl et al. 2002, 2007; Müller et al. 2010). Finally, since the publication of the three past books, the field of BVOC emissions has matured greatly in our understanding of BVOC emission models and their connection to underlying metabolic processes (Monson et al. 2012).

This book intends to cover all biological scales of organization from molecular to globe and to make a major leap in summarizing and synthesizing the existing information accumulated since the publication of the past comprehensive summaries of BVOC emissions. The book consists of 17 primary chapters followed by a synthesis. The chapters focus on four major topics: evolutionary diversification and perspectives for genetic engineering of volatile organic compound emissions (chapters 1-4), controls over emissions (chapters 5-7), emissions under stress (chapters 8-11), and emission models (chapters 12-17).

Chapters 1-4 cover tree BVOC emission diversity and evolutionary aspects as driven by abiotic (chapter of Fineschi et al.) and biotic (chapter of Trowbridge and Stoy) stresses, and molecular diversity (chapters of Rajabi Memari et al. and Rosenkranz and Schnitzler), specifically asking how and why the capacity for constitutive volatile production has evolved, what are the key biochemical pathways and factors that determine the blend of emitted volatiles. Here also the diversity in elicited emissions (chapter of Trowbridge and Stoy) and ways of genetic modification to alter emissions (chapter of Rosenkranz and Schnitzler) are analysed.

Chapters 5-7 provide an overview of the cellular and leaf-level mechanisms controlling BVOC emissions. The group of these chapters starts with short-term molecular pathway and leaf-level metabolic controls (chapters of Li and Sharkey, and Monson), then covers longer-term controls by carbon availability and gene expression level acclimation responses to environmental variability (chapter of Monson) and finishes with stomatal and physico-chemical controls driven by variations in compound volatility (chapter of Harley).

Chapters 8-11 review the effects of abiotic and biotic stresses on volatile emissions. Consideration of this topic starts with a chapter analysing the modification of tree abiotic stress tolerance by the capacity for volatile emissions, emphasizing tolerance to heat, drought, salinity and resulting oxidative stress (chapter of Possell and Loreto). Then responses of emissions to flooding (chapter of Kreutzwieser and Rennenberg) and air pollution and elevated $\left[\mathrm{CO}_{2}\right]$ (chapter of Calfapietra et al.) 
are reviewed. This topic is concluded with a chapter investigating the multitrophic interactions between trees, herbivores and herbivore enemies in future polluted atmospheres that significantly alter the role of volatile compounds as important ecological signals that organize food webs and host parasite relations (chapter of Holopainen et al.).

The chapters $12-17$ put the information summarized in previous chapters into the quantitative framework of predictive emission models. This topic starts with a review of leaf-level emission algorithms (chapter of Grote et al.), then covers canopy and landscape (chapters of Niinemets et al. and Guenther) and biome level models (chapter of Ashworth et al.), emphasizing the philosophy of model parameterization and validation. Finally, global feedbacks to climate and atmospheric composition due to tree BVOC emissions are analysed (chapter of Kulmala et al.).

The book concludes with a synthesis section that puts the contents of the book into global biosphere-atmosphere science context and provides a perspective for future developments in the field. In addition to summarizing the state-of-the-art information of tree volatile emissions, the book, in particular, explores the ways that rich archives of molecular, physiological and ecological evidence can be best included in quantitative emission models. The content and focus of the chapters are intended for use by graduate students, researchers and policy professionals interested in the recent developments in the field. As in many interdisciplinary, complex and rich science fields, the challenge in BVOC research is to get to an intellectual place beyond the fragmented, and increasingly more detailed, knowledge provided in the primary literature to one of synthetic understanding, utility for framing further hypotheses and application to devising observation and regulation policies that improve the global human condition. We hope that this book can serve as a springboard for those interested in starting a career in BVOC research, those continuing to pursue research at the frontier of this fascinating field and those interested in applying the research to the better management of our Earth system.

\section{References}

Arneth A, Niinemets Ü, Pressley S, Bäck J, Hari P, Karl T, Noe S, Prentice IC, Serça D, Hickler T, Wolf A, Smith B (2007) Process-based estimates of terrestrial ecosystem isoprene emissions: incorporating the effects of a direct $\mathrm{CO}_{2}$-isoprene interaction. Atmos Chem Phys 7:31-53

Arneth A, Harrison SP, Zaehle S, Tsigaridis K, Menon S, Bartlein PJ, Feichter J, Korhola A, Kulmala M, O’Donnell D, Schurgers G, Sorvari S, Vesala T (2010) Terrestrial biogeochemical feedbacks in the climate system. Nat Geosci 3:525-532

Behnke K, Ehlting B, Teuber M, Bauerfeind M, Louis S, Hänsch R, Polle A, Bohlmann J, Schnitzler J-P (2007) Transgenic, non-isoprene emitting poplars don't like it hot. Plant J 51:485-499

Behnke K, Kaiser A, Zimmer I, Brüggemann N, Janz D, Polle A, Hampp R, Hänsch R, Popko J, Schmitt-Kopplin P, Ehlting B, Rennenberg H, Barta C, Loreto F, Schnitzler J-P (2010) RNAimediated suppression of isoprene emission in poplar transiently impacts phenolic metabolism under high temperature and high light intensities: a transcriptomic and metabolomic analysis. Plant Mol Biol 74:61-75 
Bohlmann J, Meyer-Gauen G, Croteau R (1998) Plant terpenoid synthases: molecular biology and phylogenetic analysis. Proc Natl Acad Sci USA 95:4126-4133

Chameides W, Lindsay R, Richardson J, Kiang C (1988) The role of biogenic hydrocarbons in urban photochemical smog: Atlanta as a case study. Science 241:1473-1475

Chen F, Tholl D, Bohlmann J, Pichersky E (2011) The family of terpene synthases in plants: a mid-size family of genes for specialized metabolism that is highly diversified throughout the kingdom. Plant J 66:212-229

Degenhardt J, Koellner TG, Gershenzon J (2009) Monoterpene and sesquiterpene synthases and the origin of terpene skeletal diversity in plants. Phytochemistry 70:1621-1637

Dicke M, Baldwin IT (2010) The evolutionary context for herbivore-induced plant volatiles: beyond the 'cry for help'. Trends Plant Sci 15:167-175

Dicke M, van Loon JJA, Soler R (2009) Chemical complexity of volatiles from plants induced by multiple attack. Nat Chem Biol 5:317-324

Fischbach RJ, Zimmer W, Schnitzler J-P (2001) Isolation and functional analysis of a cDNA encoding a myrcene synthase from holm oak (Quercus ilex L.). Eur J Biochem 268:5633-5638

Fuentes JD, Lerdau M, Atkinson R, Baldocchi D, Bottenheim JW, Ciccioli P, Lamb B, Geron C, Gu L, Guenther A, Sharkey TD, Stockwell W (2000) Biogenic hydrocarbons in the atmospheric boundary layer: a review. Bull Am Meteorol Soc 81:1537-1575

Gasche R, Papen H, Rennenberg H (eds) (2003) Trace gas exchange in forest ecosystems. Kluwer, Dordrecht

Guenther AB, Monson RK, Fall R (1991) Isoprene and monoterpene emission rate variability: observations with Eucalyptus and emission rate algorithm development. J Geophys Res 96:10799-10808

Guenther A, Zimmerman PR, Wildermuth M (1994) Natural volatile organic compound emission rates for U.S. woodland landscapes. Atmos Environ 28:1197-1210

Guenther A, Karl T, Harley P, Wiedinmyer C, Palmer PI, Geron C (2006) Estimates of global terrestrial isoprene emissions using MEGAN (model of emissions of gases and aerosols from nature). Atmos Chem Phys 6:3181-3210

Guenther AB, Jiang X, Heald CL, Sakulyanontvittaya T, Duhl T, Emmons LK, Wang X (2012) The model of emissions of gases and aerosols from nature version 2.1 (MEGAN2.1): an extended and updated framework for modeling biogenic emissions. Geosci Model Dev 5:1471-1492

Hallquist M, Wenger JC, Baltensperger U, Rudich Y, Simpson D, Claeys M, Dommen J, Donahue NM, George C, Goldstein AH, Hamilton JF, Herrmann H, Hoffmann T, linuma Y, Jang M, Jenkin ME, Jimenez JL, Kiendler-Scharr A, Maenhaut W, McFiggans G, Mentel TF, Monod A, Prévôt ASH, Seinfeld JH, Surratt JD, Szmigielski R, Wildt J (2009) The formation, properties and impact of secondary organic aerosol: current and emerging issues. Atmos Chem Phys 9:5155-5236

Hewitt CN (ed) (1999) Reactive hydrocarbons in the atmosphere. Academic Press, San Diego

Holopainen JK, Gershenzon J (2010) Multiple stress factors and the emission of plant VOCs. Trends Plant Sci 15:176-184

Huff Hartz KE, Rosenørn T, Ferchak SR, Raymond TM, Bilde M, Donahue NM, Pandis SN (2005) Cloud condensation nuclei activation of monoterpene and sesquiterpene secondary organic aerosol. J Geophys Res Atmos 110:D14208. doi:14210.11029/12004JD005754

Karl TG, Spirig C, Rinne J, Stroud C, Prevost P, Greenberg J, Fall R, Guenther A (2002) Virtual disjunct eddy covariance measurements of organic compound fluxes from a subalpine forest using proton transfer reaction mass spectrometry. Atmos Chem Phys 2:279-291

Karl TG, Christian TJ, Yokelson RJ, Artaxo P, Hao WM, Guenther A (2007) The tropical forest and fire emissions experiment: method evaluation of volatile organic compound emissions measured by PTR-MS, FTIR, and GC from tropical biomass burning. Atmos Chem Phys 7:5883-5897

Keeling CI, Weisshaar S, Ralph SG, Jancsik S, Hamberger B, Dullat HK, Bohlmann J (2011) Transcriptome mining, functional characterization, and phylogeny of a large terpene synthase gene family in spruce (Picea spp.). BMC Plant Biol 11:43 
Köksal M, Zimmer I, Schnitzler J-P, Christianson DW (2010) Structure of isoprene synthase illuminates the chemical mechanism of teragram atmospheric carbon emission. J Mol Biol 402:363-373

Köksal M, Jin Y, Coates RM, Croteau R, Christianson DW (2011) Taxadiene synthase structure and evolution of modular architecture in terpene biosynthesis. Nature 469:116-120

Kulmala M, Suni T, Lehtinen KEJ, Dal Maso M, Boy M, Reissell A, Rannik Ü, Aaalto P, Keronen P, Hakola H, Bäck J, Hoffmann T, Vesala T, Hari P (2004) A new feedback mechanism linking forests, aerosols, and climate. Atmos Chem Phys 4:557-562

Loreto F, Schnitzler J-P (2010) Abiotic stresses and induced BVOCs. Trends Plant Sci 15:154-166

Loreto F, Mannozzi M, Maris C, Nascetti P, Ferranti F, Pasqualini S (2001) Ozone quenching properties of isoprene and its antioxidant role in leaves. Plant Physiol 126:993-1000

Miller B, Oschinski C, Zimmer W (2001) First isolation of an isoprene synthase gene and successful expression of the gene from poplar in E. coli. Planta 213:483-487

Monson RK, Grote R, Niinemets Ü, Schnitzler J-P (2012) Tansley review. Modelling the isoprene emission rate from leaves. New Phytol 195:541-559

Monson RK, Jones RT, Rosenstiel TN, Schnitzler J-P (2013) Why only some plants emit isoprene. Plant Cell Environ 36:503-516. doi:10.1111/pce.12015

Müller M, Graus M, Ruuskanen TM, Schnitzhofer R, Bamberger I, Kaser L, Titzmann T, Hörtnagl L, Wohlfahrt G, Karl T, Hansel A (2010) First eddy covariance flux measurements by PTRTOF. Atmos Meas Tech 3:387-395

Niinemets Ü (2010) Mild versus severe stress and BVOCs: thresholds, priming and consequences. Trends Plant Sci 15:145-153

Owen SM, Peñuelas J (2005) Opportunistic emissions of volatile isoprenoids. Trends Plant Sci 10:420-426

Pierce TE, Waldruff PS (1991) PC-BEIS - a personal-computer version of the biogenic emissions inventory system. J Air Waste Manage Assoc 41:937-941

Rasmussen RA (1970) Isoprene: identified as a forest-type emission to the atmosphere. Environ Sci Technol 4:667-671

Rasmussen R (1972) What do the hydrocarbons from trees contribute to air pollution. J Air Pollut Contr Assoc 22:537-543

Rasmussen RA (1978) Isoprene plant species list. Washington State University, Pullman

Rasmussen RA, Went FW (1965) Volatile organic material of plant origin in the atmosphere. Proc Natl Acad Sci USA 53:215-220

Sanadze GA (1956) Emission of gaseous organic substances from plants. Rep Akad Nauk Gruz SSR 17:429-433

Sharkey TD, Singsaas EL (1995) Why plants emit isoprene. Nature 374:769

Sharkey TD, Holland E, Mooney HA (eds) (1991) Trace gas emissions by plants. Academic Press, San Diego

Sharkey TD, Gray DW, Pell HK, Breneman SR, Topper L (2013) Isoprene synthase genes form a monophyletic clade of acyclic terpene synthases in the Tps-b terpene synthase family. Evolution 67:1026-1040. doi:10.1111/evo.12013

Silver GM, Fall R (1991) Enzymatic synthesis of isoprene from dimethylallyldiphosphate in aspen leaf extracts. Plant Physiol 97:1588-1591

Velikova V, Várkonyi Z, Szabó M, Maslenkova L, Nogues I, Kovács L, Peeva V, Busheva M, Garab G, Sharkey TD, Loreto F (2011) Increased thermostability of thylakoid membranes in isoprene-emitting leaves probed with three biophysical techniques. Plant Physiol 157:905-916

Vickers CE, Gershenzon J, Lerdau MT, Loreto F (2009a) A unified mechanism of action for volatile isoprenoids in plant abiotic stress. Nat Chem Biol 5:283-291

Vickers CE, Possell M, Cojocariu CI, Velikova VB, Laothawornkitkul J, Ryan A, Mullineaux PM, Hewitt CN (2009b) Isoprene synthesis protects transgenic tobacco plants from oxidative stress. Plant Cell Environ 32:520-531

Vickers CE, Possell M, Hewitt CN, Mullineaux PM (2010) Genetic structure and regulation of isoprene synthase in poplar (Populus spp.). Plant Mol Biol 73:547-558

Went FW (1960) Blue hazes in the atmosphere. Nature 187:641-643 


\section{Contents}

1 Diversification of Volatile Isoprenoid Emissions from

Trees: Evolutionary and Ecological Perspectives

Silvia Fineschi, Francesco Loreto, Michael Staudt, and Josep Peñuelas

2 BVOC-Mediated Plant-Herbivore Interactions

Amy M. Trowbridge and Paul C. Stoy

3 The Biochemistry and Molecular Biology of Volatile

Messengers in Trees

Hamid Rajabi Memari, Leila Pazouki, and Ülo Niinemets

4 Genetic Engineering of BVOC Emissions from Trees

Maaria Rosenkranz and Jörg-Peter Schnitzler

5 Molecular and Pathway Controls on Biogenic Volatile

Organic Compound Emissions

Ziru Li and Thomas D. Sharkey

6 Metabolic and Gene Expression Controls

on the Production of Biogenic Volatile Organic Compounds

Russell K. Monson

7 The Roles of Stomatal Conductance and Compound

Volatility in Controlling the Emission of Volatile Organic

Compounds from Leaves

Peter C. Harley

8 The Role of Volatile Organic Compounds in Plant

Resistance to Abiotic Stresses: Responses and Mechanisms ......... 209

Malcolm Possell and Francesco Loreto

$9 \quad$ Flooding-Driven Emissions from Trees

Jürgen Kreuzwieser and Heinz Rennenberg 
10 Modification of BVOC Emissions by Changes in Atmospheric $\left[\mathrm{CO}_{2}\right]$ and Air Pollution ....................... 253

Carlo Calfapietra, Emanuele Pallozzi, Ilaria Lusini, and Violeta Velikova

11 Multitrophic Signalling in Polluted Atmospheres 285 Jarmo K. Holopainen, Anne-Marja Nerg, and James D. Blande

12 Leaf-Level Models of Constitutive and Stress-Driven Volatile Organic Compound Emissions

Rüdiger Grote, Russell K. Monson, and Ülo Niinemets

13 Scaling BVOC Emissions from Leaf to Canopy and Landscape: How Different Are Predictions Based on Contrasting Emission Algorithms?

Ülo Niinemets, Paolo Ciccioli, Steffen M. Noe, and Markus Reichstein

14 Upscaling Biogenic Volatile Compound Emissions from Leaves to Landscapes Alex Guenther

15 Scaling Emissions from Agroforestry Plantations and Urban Habitats

Susan M. Owen, C. Nicholas Hewitt, and Clare S. Rowland

16 Global Modelling of Volatile Organic Compound Emissions

Kirsti Ashworth, Christophe Boissard, Gerd Folberth,

Juliette Lathière, and Guy Schurgers

17 Climate Feedbacks Linking the Increasing Atmospheric $\mathrm{CO}_{2}$ Concentration, BVOC Emissions, Aerosols and Clouds in Forest Ecosystems

Markku Kulmala, Tuomo Nieminen, Robert Chellapermal, Risto Makkonen, Jaana Bäck, and Veli-Matti Kerminen

18 State-of-the-Art of BVOC Research: What Do We Have and What Have We Missed? A Synthesis

Ülo Niinemets and Russell K. Monson

Editors Biography

Index 


\section{Contributors}

Kirsti Ashworth Institute for Meteorology and Climate Research - Atmospheric Environmental Research (IMK-IFU), Karlsruhe Institute for Technology (KIT), Garmisch-Partenkirchen, Germany

Jaana Bäck Department of Physics, University of Helsinki, Helsinki, Finland

Department of Forest Sciences, University of Helsinki, Helsinki, Finland

James D. Blande Department of Environmental Science, University of Eastern Finland, Kuopio, Finland

Christophe Boissard Laboratoire des Sciences du Climat et de l'Environnement LSCE-IPSL, CEA-CNRS-UVSQ, Gif-sur-Yvette, France

Carlo Calfapietra Institute of Agro-Environmental and Forest Biology (IBAF), Consiglio Nazionale delle Ricerche (CNR), Porano, TR, Italy

Robert Chellapermal Department of Physics, University of Helsinki, Helsinki, Finland

Paolo Ciccioli Istituto di Metodologie Chimiche, Consiglio Nazionale delle Ricerche (CNR), Monterotondo Scalo, Italy

Silvia Fineschi Istituto per la Protezione delle Piante (IPP), Consiglio Nazionale delle Ricerche (CNR), Sesto Fiorentino, FI, Italy

Gerd Folberth Met Office Hadley Centre, Exeter, Devon, UK

Rüdiger Grote Institute for Meteorology and Climate Research - Atmospheric Environmental Research (IMK-IFU), Karlsruhe Institute for Technology (KIT), Garmisch-Partenkirchen, Germany

Alex Guenther Biosphere-Atmosphere Interactions Group, Atmospheric Chemistry Division, Earth System Laboratory, National Center for Atmospheric Research, Boulder, CO, USA 
Peter C. Harley Biosphere-Atmosphere Interactions Group, Atmospheric Chemistry Division, Earth System Laboratory, National Center for Atmospheric Research, Boulder, CO, USA

C. Nicholas Hewitt Lancaster Environment Centre, Lancaster University, Lancaster, UK

Jarmo K. Holopainen Department of Environmental Science, University of Eastern Finland, Kuopio, Finland

Veli-Matti Kerminen Department of Physics, University of Helsinki, Helsinki, Finland

Jürgen Kreuzwieser Professur für Baumphysiologie, Albert-Ludwigs-Universität Freiburg, Freiburg im Breisgau, Germany

Markku Kulmala Department of Physics, University of Helsinki, Helsinki, Finland

Juliette Lathière Laboratoire des Sciences du Climat et de l'Environnement LSCE-IPSL, CEA-CNRS-UVSQ, Gif-sur-Yvette, France

Ziru Li Department of Biochemistry and Molecular Biology, Michigan State University, East Lansing, MI, USA

Francesco Loreto Istituto per la Protezione delle Piante (IPP), Consiglio Nazionale delle Ricerche (CNR), Sesto Fiorentino, FI, Italy

Ilaria Lusini Institute of Agro-Environmental and Forest Biology (IBAF), Consiglio Nazionale delle Ricerche (CNR), Porano, TR, Italy

Department for Innovation in Biological, Agro-Food and Forest Systems, University of Tuscia, Viterbo, Italy

Risto Makkonen Department of Physics, University of Helsinki, Helsinki, Finland

Hamid Rajabi Memari Genetic Engineering and Molecular Genetics, Biotechnology and Life Science Center and School of Agriculture, Shahid Chamran University of Ahvaz, Ahvaz, Iran

Russell K. Monson School of Natural Resources and the Environment and the Laboratory for Tree Ring Research, University of Arizona, Tucson, AZ, USA

Anne-Marja Nerg Department of Environmental Science, University of Eastern Finland, Kuopio, Finland

Tuomo Nieminen Department of Physics, University of Helsinki, Helsinki, Finland

Ülo Niinemets Department of Plant Physiology, Institute of Agricultural and Environmental Sciences, Estonian University of Life Sciences, Tartu, Estonia 
Steffen M. Noe Department of Plant Physiology, Institute of Agricultural and Environmental Sciences, Estonian University of Life Sciences, Tartu, Estonia

Susan M. Owen Biosphere Atmosphere Interactions, Centre for Ecology and Hydrology, Penicuik, Midlothian, UK

Emanuele Pallozzi Institute of Agro-Environmental and Forest Biology (IBAF), Consiglio Nazionale delle Ricerche (CNR), Porano, TR, Italy

Leila Pazouki Institute of Agricultural and Environmental Sciences, Estonian University of Life Sciences, Tartu, Estonia

Josep Peñuelas CSIC, Global Ecology Unit, CREAF-CEAB-UAB, Catalonia, Spain

CREAF, Catalonia, Spain

Malcolm Possell Faculty of Agriculture and Environment, University of Sydney, Sydney, NSW, Australia

Markus Reichstein Max Planck Institute for Biogeochemistry, Jena, Germany

Heinz Rennenberg Professur für Baumphysiologie, Albert-Ludwigs-Universität Freiburg, Freiburg im Breisgau, Germany

Maaria Rosenkranz Research Unit Environmental Simulation (EUS), Institute of Biochemical Plant Pathology, Helmholtz Zentrum München, Neuherberg, Germany

Clare S. Rowland Monitoring and Observation Systems, Centre for Ecology and Hydrology, Lancaster, UK

Jörg-Peter Schnitzler Research Unit Environmental Simulation (EUS), Institute of Biochemical Plant Pathology, Helmholtz Zentrum München, Neuherberg, Germany

Guy Schurgers Department of Physical Geography and Ecosystem Science, Lund University, Lund, Sweden

Thomas D. Sharkey Department of Biochemistry and Molecular Biology, Michigan State University, East Lansing, MI, USA

Michael Staudt Centre d'Ecologie Fonctionnelle et Evolutive, UMR 5175, Montpellier cedex 5, France

Paul C. Stoy Department of Land Resources and Environmental Sciences, Montana State University, Bozeman, MT, USA

Amy M. Trowbridge Department of Land Resources and Environmental Sciences, Montana State University, Bozeman, MT, USA

Violeta Velikova Institute of Plant Physiology and Genetics, Bulgarian Academy of Sciences, Sofia, Bulgaria 